\title{
Diversity of hydrolytic enzymes in haloarchaeal strains isolated from salt lake
}

\author{
A. Makhdoumi Kakhki; "M. A. Amoozegar; E. Mahmodi Khaledi \\ Extremophiles Laboratory, Department of Microbiology, College of Science, University of Tehran, Tehran, Iran \\ Received 16 January 2011; revised 30 June 2011; accepted 16 August 2011; available online 1 September 2011
}

\begin{abstract}
Production of ten hydrolytic enzymes was qualitatively studied on the haloarchaeal strains isolated from Aran-Bidgol hypersaline lake in the central desert area of Iran. A total of 293 haloarchea strains were selected among 300 extremely halophilic isolated prokaryotes. Accordingly, 142, 141, 128, 64, 38, 16, 7, 3 and 1 archaeal isolates were able to produce DNase, amylase, lipase, inulinase, pullulanase, protease, cellulase, chitinase and xylanase, respectively. None was able to produce pectinase activity. Combined hydrolytic activity was also detected in many strains. A total of $0.3 \%$ of the strains showed 6 hydrolytic activities, $0.3 \%$ of the strains had 5 hydrolytic activities, $5.4 \%$ of the strains presented 4 hydrolytic activities, $25 \%$ of the strains presented 3 hydrolytic activities, $28 \%$ of the strains presented 2 hydrolytic activities and $18 \%$ of the strains presented 1 hydrolytic activity. According to their phenotypic characteristics and comparative partial $16 \mathrm{~S}$ rRNA sequence analysis, the halophilic strains were all identified as members of family Halobacteriaceae within 12 different taxa from the following genera: Halorubrum, Haloarcula, Natrinema, Halovivax and Natronomonas. Most enzymes production rate was observed in the genera Halorubrum, Haloarcula and Natrinema whereas; there was not any detectable amount of enzyme production in the genera Halovivax and Natronomonas. The most hydrolytic isolate with 6 combinatorial enzyme production belonged to the genus Natrinema. This investigation showed that the extreme halophilic archaea from Aran-Bidgol lake are a potential source of hydrolytic enzyme under stress conditions and may have possess commercial value.
\end{abstract}

Keywords: Archaea; Biodiversity; Enzyme; Hypersaline environment

\section{INTRODUCTION}

Haloarchaea in order Halobacterials and family Halobacteriaceae are extreme halophiles requiring at least 1.5 molar $\mathrm{NaCl}$ for growth (Grant et al., 2001). These microorganisms were distributed all over the world in different natural hypersaline lake (Maturrano et al., 2006; Mutlu et al., 2008; Caton et al., 2009) or artificial crystallizer ponds (Benlloch et al., 2001; Burns et al., 2004; Oh et al., 2009; Pasic et al., 2005). Likewise they found in environment with lower salinity (Elshahed et al., 2004; Purdy et al., 2004). Halophilic archaea in comparison with to halophilic bacteria which contain a cytoplasm with low concentration of salt due to produce compatible solute, use high salt in strategy in order to survive osmotic challenges associated with life in hypersaline environments (Madigan and Oren, 1999; Lin et al., 2011). Thus, they have enzymes which are active up to $5 \mathrm{M}$ or more concentration of $\mathrm{NaCl}$ or

주사. Corresponding Author Email: amozegar@khayam.ut.ac.ir Tel.: +98-21-61113557; Fax: +98-21-66492992
4M KCl (Danson and Hough, 1997). Extremoenzymes from halophilic archaea not only are extremely high salt tolerant but also they are termotolerant because of the specific environment they live. These kinds of enzymes have catalytic function in the condition of low water activity, the situation that is common in the presence of organic solvents (Marhuenda-Egea and Bonete, 2002), which are known as the better environment for some enzymatic reactions (Serdakowski and Dordick, 2008). Most industrial processes are carried out in very harsh physicochemical conditions which may not be definitively adjusted to the optimal points required for the activity of the available enzymes. Thus, it would be of great importance to have extremozymes that expose optimal activities at high salinity, temperature and $\mathrm{pH}$ values. Haloarchaeal hydrolytic enzymes seem to be very good candidate for industrial application which are not only love salt, but also may be excellent activity 
at high temperature, low water activity and high $\mathrm{pH}$ value.

Hypersaline lakes, with salinity ranges at or near saturation are distributed all over the world and they fall into two categories according to their origin: thalassohaline and athalassohaline. Thalassohaline lakes are those that originated by evaporation of seawater and having an ionic composition reflecting that of seawater, with $\mathrm{Na}^{+}$as the dominant cation and $\mathrm{Cl}^{-}$as the dominant anion. On the other hand athalassohaline environments are natural brines that have ionic compositions differ from seawater. Hypersaline environments have considerable diversity regarding extremely halophilic archaea as well as halophilic and halotolerant bacteria.

There are several hypersaline lakes in Iran in both mentioned categories which their microbial population remained to be identified. During the study of microbial population in Aran-Bidgol salt lake in Iran (in progress), diversity of ten hydrolytic enzymes including: amylase, cellulase, chitinase, DNase, inulinase, lipase, pectinase, protease, pullulanase, and xylanase were qualitatively studied.

Despite advances in understanding the diversity and systematic of haloarchaea, studying their hydrolytic enzymes received less attention. However some special haloarchaeal enzymes are characterized in details (Ruiz and De Castro, 2007; De Castro et al., 2008; Müller-Santos et al., 2009). The aim of this study which carried out during 2007-2010 at the extremophiles lab, University of Terhran, Iran was firstly to describe the overview potential of enzymatic production in haloarchaeal population by investigating 293 archaeal strains and secondly was to compare them to haloarchaeal found in other hypersaline lake as well as to halophilic bacteria.

\section{MATERIALS AND METHODS}

Site description, Sample collection and growth condition

Aran-Bidgol lake, in the centre of Iran, is a hypersaline lake and the largest playa in Iran at an altitude of $800 \mathrm{~m}$ and $1000 \mathrm{~km}$ from the coast (Fig. 1). This playa had been formed by deposition of halite sediments in different geological periods. Sediments are dissolved by rainfall at winter season and salt is formed by high-rate evaporation in dry season and harvested commercially. The lake shape is triangular with an area of about $2400 \mathrm{~km}^{2}$. The $\mathrm{pH}$ value of the lake is neutral (about $\mathrm{pH} 7.1$ ) and its salinity reaches to saturation in dry season.

Samplings were carried out in dry season (JulyNovember 2007) from nine different sites of the lake samples including multi-color brine, salt and salin-mud were collected in sterile plastic containers. The temperature and $\mathrm{pH}$ of the sampling sites were between $30-38^{\circ} \mathrm{C}$ and 7.0-7.8, respectively. The Modified growth medium (MGM) with $23 \%$ total salt concentration from Halohandbook online protocol used for the isolation procedure (Dyall-Smith, 2008). It contains the $23 \%$ salt water from $30 \%$ stock solution consists of $(\mathrm{g} / \mathrm{L}): \mathrm{NaCl}$ $240, \mathrm{MgSO}_{4} 35, \mathrm{MgCl}_{2} 30, \mathrm{KCl} 7$ and $\mathrm{CaCl}_{2} 1$

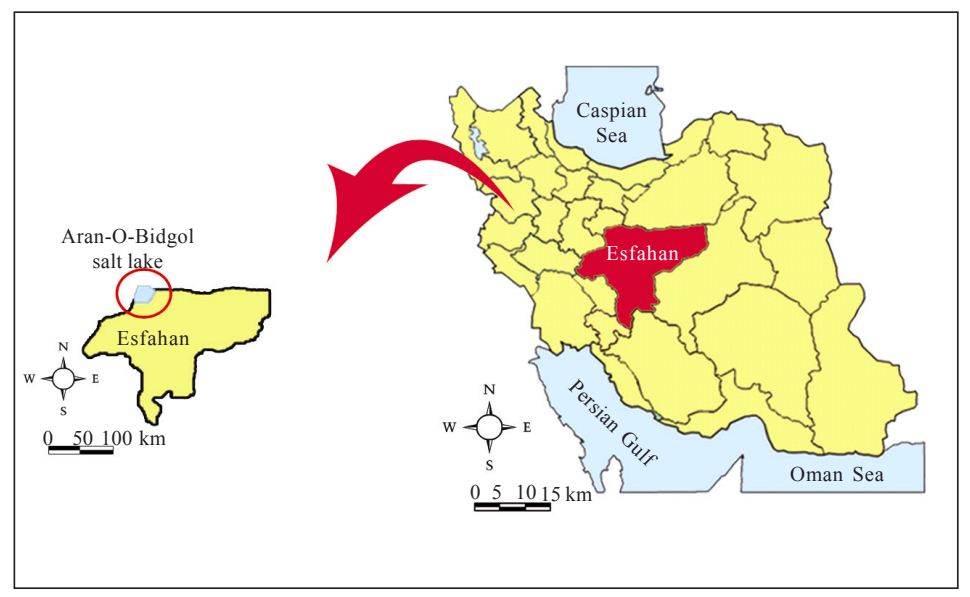

Fig. 1: Location map of the studied area 
supplemented by $10 \mathrm{~g} / \mathrm{L}$ peptone and $2 \mathrm{~g} / \mathrm{L}$ yeast extract. $15 \mathrm{~g} / \mathrm{L}$ agar was used for solidified the media if necessary. The $\mathrm{pH}$ of media was adjusted on 7.2-7.4 with Tris-base buffer (Merck). All samples were cultured in $23 \%$ MGM media after prepare the appropriate dilution at the laboratory, cultivation also carried out immediately at the lake. Cultures were incubated at $40{ }^{\circ} \mathrm{C}$ up to two months. Pure isolates were obtained by successively cultivation on solid MGM medium. Strains were stored in sealed plates in refrigerator for some months. Liquid nitrogen storage was used for long time preservation.

\section{Screening for Haloarchaea}

Haloarchaeal strains were selected among all isolates by their susceptibility to anisomycin antibiotic (Santa cruz, USA)(Pecher and Bock, 1981). Antibiotic susceptibility test were studied according to disk diffusion method by the concentration of $30 \mu \mathrm{g}$ antibiotic per disk.

\section{Screening of strains for extracellular hydrolytic activities}

In order to qualitative detection of producing of extracellular hydrolyses, different enzymatic agar plate assays were performed with the only exception of the pullulanase activity assay which was performed in liquid medium. Standard methods which referenced in each part were modified to make suitable condition for growth of haloarchae. The $\mathrm{pH}$ of all media was adjusted on 7.27.4 with Tris-base buffer. The different assay-media used are described below.

\section{Determination of extracellular amylase activity}

The presence of amylolytic activity on plates was determined qualitatively by following the method described by Amoozegar et al. (2003), using starch agar medium (Merck) containing $23 \%(\mathrm{w} / \mathrm{v})$ total salt. After incubation at $40{ }^{\circ} \mathrm{C}$ for 21 days, the plates were flooded with $0.3 \% \mathrm{I}_{2}-0.6 \% \mathrm{KI}$ solution; a clear zone around the growth indicated the hydrolysis of starch.

\section{Determination of extracellular cellulase (CMCase) activity}

CMCase activity of the isolates was screened in a solid medium. The following components were added to 23\% solid MGM medium: carboxy methyl cellulose $(\mathrm{CMC}) 5 \mathrm{~g} / \mathrm{L} ; \mathrm{NaNO}_{3} 1 \mathrm{~g} / \mathrm{L} ; \mathrm{K}_{2} \mathrm{HPO}_{4} 2 \mathrm{~g} / \mathrm{L}$ and glucose 1 $\mathrm{g} / \mathrm{L}$. After incubation at $40{ }^{\circ} \mathrm{C}$ for 21 days, the plates were flooded with $0.1 \%$ Congo red solution. The clear zone around the colony indicated cellulase activity (Zhou and Li, 2004).

\section{Determination of extracellular chitinase activity}

Modified medium presented by Park et al. (2000), was used for determining the chitinase production by the isolates. $1 \mathrm{~g} / \mathrm{L}$ Colloidal chitin was added to $23 \%$ solid MGM media. The pepton was omitted from the MGM media component. The clear zones around colonies after 21 days incubation of cultures at $40^{\circ} \mathrm{C}$ indicated qualitative chitinase activity.

\section{Determination of extracellular DNase activity}

DNase activity of the strains was determined using $42 \mathrm{~g} / \mathrm{L}$ of DNase test agar medium (Merck), supplemented with $23 \%$ total salt and $0.008 \mathrm{~g} / \mathrm{L}$ toluiden blue. After incubation at $40{ }^{\circ} \mathrm{C}$ for 21 days, the plates were flooded with $1 \mathrm{~N} \mathrm{HCl}$ solution. Clear halos around the colonies showed DNase activity (Onishi et al., 1983).

\section{Determination of extracellular inulinase activity}

The production of inulinase by halophilic archaea was detected by preparing media containing inulin 2 $\mathrm{g} / \mathrm{L},\left(\mathrm{NH}_{4}\right)_{2} \mathrm{SO}_{4} 0.5 \mathrm{~g} / \mathrm{L}, \mathrm{KH}_{2} \mathrm{PO}_{4} 3 \mathrm{~g} / \mathrm{L}$, agar $20 \mathrm{~g} / \mathrm{L}$, supplemented with $23 \%$ total salt. Filtrated inulin was used as the sole source of carbon in this medium; thus, Haloarchaeal growth after 21 days of incubation at $40{ }^{\circ} \mathrm{C}$ showed the presence of inulinase activity (Allais et al., 1986).

\section{Determination of extracellular lipase activity}

Modified media presented by Samad et al. (1989) were used for study the lipolytic activity. Pepton was omitted from $23 \%$ solid MGM and olive oil substituted at $10 \mathrm{~g} / \mathrm{L}$ concentrations after media was autoclaved. White sediment around the growth after 21 days incubation at $40{ }^{\circ} \mathrm{C}$ showed the lipase activity.

\section{Determination of extracellular pectinolytic activity}

The presence of pectinolytic activity on the plates was determined using a modified medium proposed by Soares et al. (1999), which containing pectin $5 \mathrm{~g} /$ $\mathrm{L},\left(\mathrm{NH}_{4}\right)_{2} \mathrm{SO}_{4} 1.4 \mathrm{~g} / \mathrm{L}, \mathrm{K}_{2} \mathrm{HPO}_{4} 2 \mathrm{~g} / \mathrm{L}$ and nutrient solution $1 \mathrm{~g} / \mathrm{L}\left(\mathrm{FeSO}_{4} \cdot 7 \mathrm{H}_{2} \mathrm{O}, 5 \mathrm{mg} / \mathrm{L} ; \mathrm{MnSO}_{4} \cdot \mathrm{H}_{2} \mathrm{O}, 1.6\right.$ $\left.\mathrm{mg} / \mathrm{L}, \mathrm{ZnSO}_{4} .7 \mathrm{H}_{2} \mathrm{O}, 1.4 \mathrm{mg} / \mathrm{L} ; \mathrm{CaCl}_{2}, 2 \mathrm{mg} / \mathrm{L}\right)$, these components were added to $23 \%$ solid MGM media free of peptone. After incubation at $40{ }^{\circ} \mathrm{C}$ for 21 days, the plates were flooded with $0.3 \% \mathrm{I}_{2}-0.6 \% \mathrm{KI}$ 
solution. A clear zone around the growth showed pectinolytic activity.

\section{Determination of extracellular protease activity}

Proteolytic activity of the cultures was screened in $23 \%$ solid MGM media supplemented by $20 \mathrm{~g} / \mathrm{L}$ skim milk. Clear zones around the growth after 21 days in $40{ }^{\circ} \mathrm{C}$ were taken as evidence of proteolytic activity (Amoozegar et al., 2008).

\section{Determination of extracellular pullulanase activity}

To detect pullulanase activity, the strains were cultured in liquid medium containing yeast extract $2 \mathrm{~g} /$ $\mathrm{L}$; pullulan $5 \mathrm{~g} / \mathrm{L}$ and $23 \%$ total salt. Cultures were incubated for 21 days at $40{ }^{\circ} \mathrm{C}$. Clearness of medium after the addition of $97 \%$ ethanol indicated that the strains produced pullulanase (Ruben et al., 1993).

\section{Determination of extracellular xylanase activity}

Xylanase activity was detected using a $23 \%$ solid MGM medium containing xylan $10 \mathrm{~g} / \mathrm{L}$. After incubation at $40{ }^{\circ} \mathrm{C}$ for 21 days, the plates were flooded with $0.1 \%$ Congo red solution. The clear zones around colonies indicated qualitative xylanase activity (Wejse and Ingvorsen, 2003).

\section{Identification of the isolates}

Morphological and physiological characteristics of the isolates were either studied on solid or broth $23 \%$ MGM medium. Growth at different salt concentrations $(5,10,15,20,25$, and $30 \%, w / v)$ was tested on MGM broth at $\mathrm{pH}$ 7.2. Growth was monitored by turbidity at OD600 using a spectroscopic method (model UV-160 A; Shimadzu).

Some strains were randomly selected considering to their potential of producing extracellular hydrolytic enzymes and studied in detail. The genomic DNA of these strains was extracted by DNA extraction kit (Roch, Germany) according to the manufacturer's recommended procedure and the $16 \mathrm{~S}$ rRNA gene was amplified using the archaeal universal primers: $21 \mathrm{~F}$ (5'-TTCCGGTTGATCCYGCCGGA-3') and 1492R (5'GGTTACCTTGTTACGACTT-3'). A Polymerase chain reaction (PCR) cycler (SensoQuest) was used for this amplification. Amplification reactions contained $1.5 \mu \mathrm{L}$ of each primer, dNTP $(10 \mathrm{mM}) 1 \mu \mathrm{L}, \mathrm{PCR}$ buffer $5 \mu \mathrm{L}$, $\mathrm{MgCl}_{2}(50 \mathrm{mM}) 1.5 \mu \mathrm{L}$, template DNA $4 \mu \mathrm{L}$, DNA polymerase $0.25 \mu \mathrm{L}$, and $\mathrm{dH}_{2} \mathrm{O} 35.25 \mu \mathrm{L}$, in a final volume of $50 \mu \mathrm{L}$. The following conditions were used in the amplification of $16 \mathrm{~S}$ rRNA gene: $94{ }^{\circ} \mathrm{C}$ for $2 \mathrm{~min}$, followed by 30 cycles of $94{ }^{\circ} \mathrm{C}$ for $15 \mathrm{~s}, 51^{\circ} \mathrm{C}$ for $30 \mathrm{~s}$ and $72{ }^{\circ} \mathrm{C}$ for $60 \mathrm{~s}$, with final $7 \mathrm{~min}$ extension at $72{ }^{\circ} \mathrm{C}$. The PCR products were then checked on agarose gel with ethidium bromide staining. PCR product purification was conducted using PCR purification kit (Bioneer, South Korea). The purified PCR product was sequenced using an automated sequencer by Microgene Company (South Korea). The phylogenic relationship of the isolates was determined by comparing the sequencing data with the related $16 \mathrm{~S}$ rRNA gene sequences in the GenBank database of the National Center for Biotechnology Information, via Basic local alignment search tool (BLAST). Phylogenetic analysis was performed using the software packages PHYLIP (Felsenstein, 1993) and MEGA version 4 (Kumar et al., 2004) after obtaining multiple alignments of data available from public databases by CLUSTAL-X (Thompson et al., 1997). Pairwise evolutionary distances were computed using the correction method (Jukes and Cantor, 1969) and clustering was performed using the neighbor-joining method (Saitou and Nei, 1987). Bootstrap analysis was used to evaluate the tree topology of the neighborjoining data by performing 1,000 re-sampling (Felsenstein, 1985).

\section{RESULTS AND DISCUSSION}

Isolation of halophilic Archaea from Aran-Bidgol salt lake

Diversity of hydrolytic enzymes production was qualitatively studied on the haloarchaeal strains isolated from Aran-Bidgol hypersaline environment in Iran. The salinity of the lake was between $30 \%-33 \%$

Table 1: Chemical composition of Aran-Bidgol salt lake

\begin{tabular}{lc}
\hline Parameter & Ion concentration $(\mathrm{g} / \mathrm{L})$ \\
\hline $\mathrm{Na}^{+}$ & 88.4 \\
$\mathrm{Mg}^{2+}$ & 8.8 \\
$\mathrm{Ca}^{2+}$ & 0.28 \\
$\mathrm{~K}^{+}$ & 2.5 \\
$\mathrm{Mn}^{+}$ & 0.0004 \\
$\mathrm{~F}^{2+}$ & 0.0002 \\
$\mathrm{Cl}^{-}$ & 191.5 \\
$\mathrm{SO}_{4}{ }^{2-}$ & 4.1 \\
$\mathrm{HCO}_{3}{ }^{-}$ & 0.005 \\
$\mathrm{CO}_{3}{ }^{-}$ & $<0.0001$ \\
$\mathrm{Salinity}(\%)$ & 33 \\
$\mathrm{pH}$ & 6.95 \\
Temperature $\left({ }^{\circ} \mathrm{C}\right)$ & 38 \\
\hline
\end{tabular}


and can be considered as thalassohaline which means the $\mathrm{Na}^{+}$and $\mathrm{Cl}^{-}$are two common ions. Table 1 characterized some description of sampling site as well as brine composition. A total of 300 isolates from all strains obtained from this lake were selected randomly for further study. 293 strains of them were identified as haloarchaea as they were susceptive to anisomycin antibiotic. All 7 anisomycin resistant strains (including some red-pigmented) were confirmed to be bacteria by $16 \mathrm{~S}$ rRNA PCR-amplification and sequencing (Data are not shown).

\section{Enzymatic activity of haloarchaeal isolates}

The ability of producing ten different hydrolyses enzymes was tested qualitatively among haloarchaeal strains isolated from Aran-Bidgol salt lake (Table. 2). A total of 142, 141, 128, 64, 38, 16, 7, 3 and 1 archaeal isolates were able to produce DNase, amylase, lipase, inulinase, pullulanase, protease, cellulose, chitinase and xylanase respectively. None was able to produce pectinase activity. It is interesting to note that combined hydrolytic activity was also detected in many halophilic strains. One strain presented 6 hydrolytic activities, 1 strain presented 5 hydrolytic activities, 16 strains presented 4 hydrolytic activities, 73 strains presented 3 hydrolytic activities, 81 strains presented 2 hydrolytic activities, 53 strains presented 1 hydrolytic activity and it could not be detected any hydrolytic activity in 69 strains. Amylase, DNase and lipase are the most common hydrolytic enzymes among isolated strains by $48 \%, 48 \%$ and $43 \%$ abundance respectively.
Inulinase and pullulanase have an intermediate diversity while $23 \%$ and $13 \%$ of the strains show these hydrolytic activities. The rare rate of protease, cellulase, chitinase, xylanase were observed.

\section{Characterization of the isolates}

All of the isolates were extremely halophile and were not able to grow under $1.5 \mathrm{M}$ salt and grew optimally at 2.5 M salt or higher. Most of them were orange, red and pink pigmented but some colorless colonies were also obtained. Most of them were polymorph (short rods, triangles, flat disks, squares) whereas some coccus cells were also observed. All strains stained Gram-negative. The phylogenetic affiliations of the isolates were revealed by $16 \mathrm{~S}$ rRNA gene sequencings. The strains were all belonged to the family Halobacteriaceae from the following genra: Halorubrum (54\%), Haloarcula (18\%), Halovivax (2 $\%)$, Natrinema (4\%) and Natronomonas (3\%). The tree showing the phylogenetic position of the isolates is represented in Fig 2.

Halorubrum as predominant genus in our isolates showed high rate of amylase, lipase, pullulanase, inulinase and DNase production. The most common hydrolytic enzymes in Halorubrum genus was amylase. Moreover, amylase, protease, lipase, pullulanase, xylanase, CMCase, inulinase and DNase activity were observed in the isolates belonged to Haloarcula genus. Lipase was the most common enzymes in this genus where more than $60 \%$ of the strains showed this hydrolytic activity. The only strain with xylanase

Table 2: Rate of hydrolytic enzymes production by haloarchaeal and bacterial strains. Data were obtained form 1: Lizama et al. (2001), 2: Elevi et al. (2004), 3: Ozcan et al. (2006), 4: Birbir et al. (2007), 5: Anikandan et al. (2009), 6: Unpublished data (bacterial strains) and current study.-: not determined

\begin{tabular}{llllllll}
\hline Enzyme & Current study & 1 & 2 & 3 & 4 & 5 & 6 \\
\hline Amylase & $48 \%$ & $20 \%$ & $85 \%$ & $30 \%$ & $66 \%$ & $14 \%$ & $38 \%$ \\
Cellulase & $2 \%$ & - & - & - & $83 \%$ & - & $13 \%$ \\
Chitinase & $1 \%$ & - & - & - & - & - & $24 \%$ \\
DNase & $48 \%$ & - & - & - & $33 \%$ & $14 \%$ & $48 \%$ \\
Inulinase & $21 \%$ & - & - & - & - & - & $48 \%$ \\
Lipase & $43 \%$ & $20 \%$ & $0 \%$ & $53 \%$ & $83 \%$ & $0 \%$ & $32 \%$ \\
Pectinase & 0 & - & - & - & - & - & $28 \%$ \\
Protease & $5 \%$ & - & $0 \%$ & $31 \%$ & $33 \%$ & $64 \%$ & $24 \%$ \\
Pullulanase & $13 \%$ & - & - & - & - & - & $19 \%$ \\
Xylanase & $0.3 \%$ & - & - & - & - & - & $10 \%$ \\
\hline
\end{tabular}




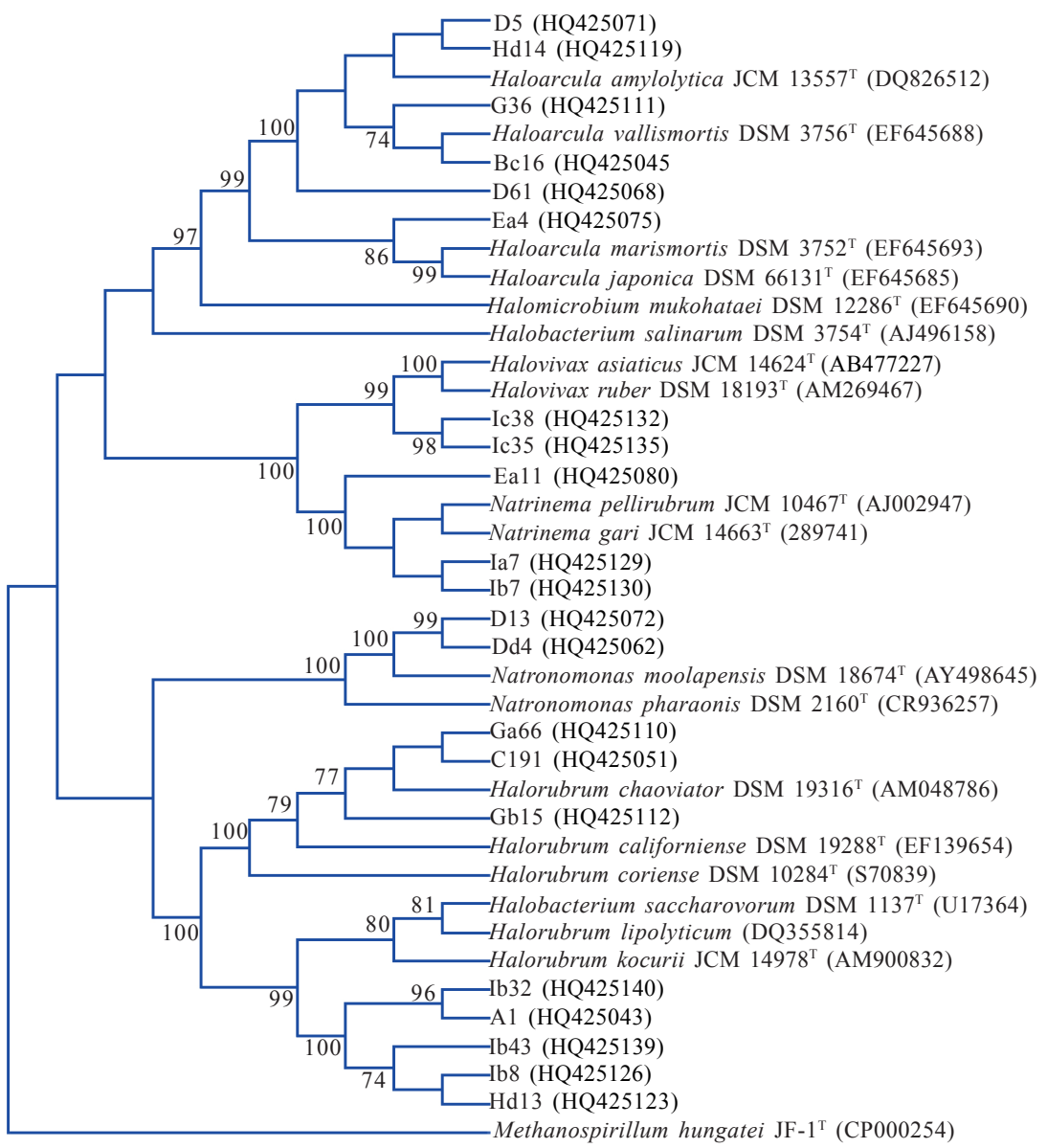

Fig. 2: Phylogenetic tree showing the position of the haloarchaea isolates, based on the partial $16 \mathrm{~S}$ rRNA gene sequence comparison, obtained by the neighbour-joining method. The accession numbers are included in brackets. The sequences of the metanogenic archaeon Methanospirillum hungatei JF- $1^{\mathrm{T}}$ (CP000254) was used as an outgroup. Bootstrap values (\%) are based on 1000 replicates and indicated on the branches

activity was also belonged to Haloarcula. Protease, lipase, pullulanase, CMCase, chitinase and inulinase activity were observed in the Natrinema genus. All of the strains belonged to this genus had lipase and protease activity. On the other hand there was not any detectable amount of enzymes production in the genera Halovivax and Natronomonas according the methods were used in this study (Fig 3). The most potent isolate with 6 combinatorial enzymes production was belong to Natrinema genus.

Although microbial diversity of hypersaline environment received high attention during last decade, only a few studies have been carried out concerning the production of extracellular enzymes from haloarchaea as predominant microbiota of these extreme environments. Lizama et al. (2001) during the study on haloarchaeal strains isolated from salt lake in Chile showed their isolates produced amylase and lipase. Elevi et al. (2004) studied the production of amylase, protease and lipase in haloarchaea. They showed high rate of amylase production but neither protease nor any lipase activity were observed. Ozcan et al. (2006) and Birbir et al. (2007) showed amylase, protease, lipase and amylase, protease, lipase cellulase, nuclease activity in the haloarchaeal strains, respectively. Anikandan et al. (2009) could detect amylase, protease, 

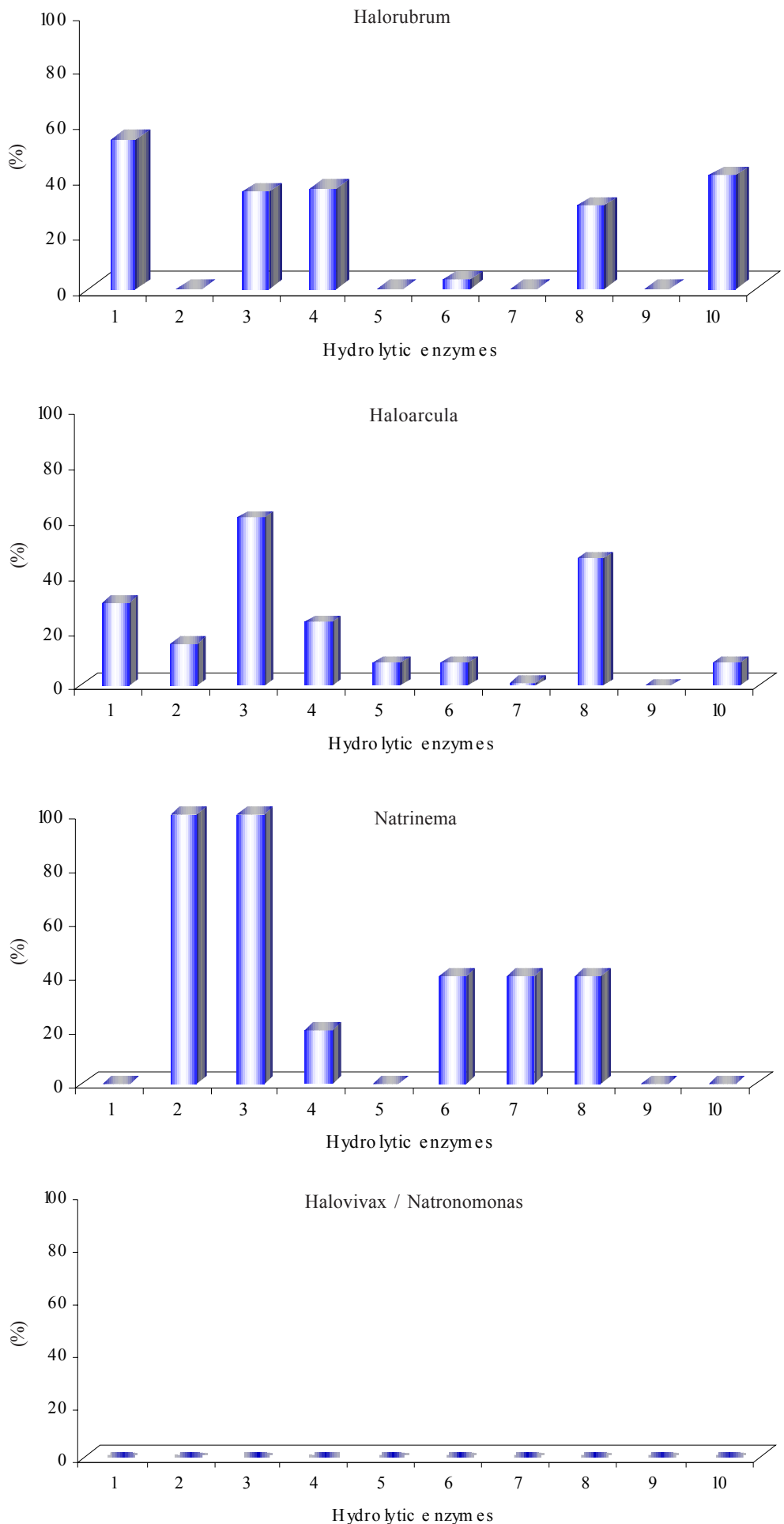

Fig. 3: Hydrolytic activities among the representatives of the genera Halorubrum, Haloarcula, Natrinema, Halovivax and Natronomonas. 1, amylase; 2, protease; 3, lipase; 4, pullulanase; 5 , xylanase; 6, CMCase; 7, chitinase; 8 , inulinase; 9 , pectinase; 10 , DNase 
DNase but no lipase activity on the haloarchaea they isolated. In this study, by investigating 293 haloarchaeal strains, high rate production of amylase, DNase and lipase could be detected in thenisolated strains which support the result of previous studies in other hypersaline habitats but the rate of strains showing cellulase and protease activity is lower in this study (Table 2). To our knowledge there are no reports for inulinase and pullulanase activity in haloarchaea to date and these hydrolytic activities in haloarchaeal strains could be shown for the first time. There was rare amount of strains which could produce chitinase and xylanase; only 3 and 1 strains had chitinase and xylanase activity among all 293 tested strains respectively. None of our haloarchaeal strains produced the pectinase. Also enzymatic activity in 69 isolates could not be detected. In the unpublished study of diversity the hydrolytic enzymes among bacterial strains isolated from this lake, all bacterial strains showed enzymatic activity (Table 2 column 5). Rohban et al. (2009) which examined the hydrolytic enzymes production in bacterial strains isolated from other hypersalin lake in Iran reported the same results and all of the bacterial strains had the ability to produce enzymes. They also isolated the strains with capability of nine combinatorial enzyme productions. From these data and other reports about hydrolytic enzymes activity in halophilic bacteria isolated from all over the world, it seems that the production rates of hydrolytic enzymes in halophilic bacteria are more than halophilic archaea (Sanchez-Porro et al., 2002; Rohban et al., 2009). Haloarchaea are growth very slowly in compare to halophilic bacteria and they may produce undetectable amounts of enzymes that maybe enough for their slowly growth in such extreme environment as they expense high amount of energy to survive in deathly condition. Although they have enzymes with very specific properties in compare to their bacterial relatives.

The phylogenetic analysis revealed that Halorubrum and Haloarcula are two dominant haloarchaeal genera with high rate enzymes production. Likewise Birbir and coworkers represented the enzymatic activity in Halorubrum, Haloarcula and Halobaterium spp (Birbir et al., 2007). According to Lizama et al. (2001) the most enzymatic productive strains belonged to the genus Halorubrum. In a study by Anikandan et al. (2009) the high rate protease production was observed in species belonged to the
Halorubrum, Haloarcula, Halobacterium genera. The results of previous studies and what was observed in this study suggest that the genus Halorubrum and Haloarcula have high rate of enzymes productions. Halorubrum and Haloarcula are common microorganisms in the diversity study of hypersaline environment by both molecular (Burns et al., 2004; Pasic et al., 2005; Mutlu et al., 2008) or cultivation (Benlloch et al., 2001; Mutlu et al., 2008) based methods. It seems high enzymatic production rate may have benefit for them to be the dominant of population. According to the results of this study, it is suggested that Natrinema genus is very good candidate for production the hydrolytic enzymes.

\section{CONCLUSION}

The diversity of hydrolytic enzymes activity in haloarchaeal strains isolated from hypersaline environment was surveyed in this study. According to the results strains belonged to the genera Halorubrum, Haloarcula and Natrinema showed the most enzymatic activity. For the first time the presence of inulinase and pullulanase was reported in haloarchaea.

Enzymes from extreme halophiles are expected to show optimal activities in extreme conditions like, low water activity, presence of organic solvents and relatively high temperature and $\mathrm{pH}$, thus the possibility to have a wide variety of extreme halophiles (Haloarchaea) producing extracellular hydrolytic enzymes will be of valuable importance for biotechnological applications. The ability of haloarchaeeal enzyme to be active in organic solvent environment instead of watery condition, offer a new horizon to biocatalyst to obtained products with very special properties. The low level of contamination due to the high salt concentration in their culture media is another benefit for industrial application of haloarchaea.

Despite the advantages of haloarchaeal extremozymes, the industrial application of them has posed some challenges. Slow growth rate, requiring high amount of salt and low rate of enzyme production are their limitations. The overall knowledge about haloarchaea physiology, genetic engineering and process engineering is currently advancing. Getting faster archaeal growth, produces archaeal enzymes in the heterologous host; thereby, bioreactor resistant to corrosion will allow further adaptation to industrial 
needs, exploration of novel applications and protection of the environment (Egorova and Antranikian, 2007).

\section{ACKNOWLEDGEMENTS}

This work was supported by the grant from International Foundation for Science (IFS) (A/4527-1).

\section{REFERENCES}

Allais, J. J.; Kammoun, S.; Blanc, P.; Girard, C.; Baratti, J. C., (1986). Isolation and characterization of bacterial strains with inulinase activity. Appl. Environ. Microbiol., 52 (5), 1086-1090 (5 pages).

Amoozegar, M. A.; Malekzadeh, F.; Malik, K. A., (2003). Production of amylase by newly isolated moderate halophile Halobacillus sp. Strain MA-2. J. Microbiol. Methods., 52 (3), 353-359 (7 pages).

Amoozegar, M. A.; Schumann, P.; Hajighasemi, M.; Fatemi, A. Z., (2008). Salinivibrio proteolyticus sp. nov. a moderately halophilic and proteolytic species from a hypersaline lake in Iran. Int. J. Syst. Evol. Microbiol., 58 (5), 1159-1163 (5 pages).

Anikandan, M.; Kannan, V.; Pašic, L., (2009). Diversity of microorganisms in solar salterns of Tamil Nadu, India. World J. Microb. Biotech., 25 (6), 1007-1017 (11 pages).

Benlloch, S.; Acinas, S. G.; Anton, J.; Lopez-Lopez Luz, S. P.; Rodriguez-Valera, F., (2001). Archaeal biodiversity in crystallizer ponds from a solar saltern: Culture versus PCR. Microb. Ecol., 41 (1), 12-19 (8 pages).

Birbir, M.; Calli, B.; Mertoglu, B.; Bardavid, R.; Oren, A.; Ogmen, M.; Ogan, A., (2007). Extremely halophilic Archaea from Tuz Lake, Turkey, and the adjacent Kaldirim and Kayacik salterns. World. J. Microbiol. Biotech., 23 (3), 309316 (8 pages).

Burns, D. G.; Camakaris, H. M.; Janssen, P. H.; Dyall-Smith, M. L., (2004). Combined use of cultivation-dependent and cultivation-independent methods indicates that members of most haloarchaeal groups in an Australian crystallizer pond are cultivable. Appl. Environ. Microbiol., 70 (9), 52585265 (8 pages)

Caton, T. M.; Caton, I. R.; Witte, L. R.; Schneegurt, M. A., (2009). Archaeal Diversity at the Great Salt Plains of Oklahoma Described by Cultivation and Molecular Analyses. Micro. Ecol., 58 (3), 519-528 (10 pages).

Danson, M. J.; Hough, D. W., (1997). The structural basis of protein halophilicity. Comp. Biochem. Physiol., 117 (3), 307-312 (6 pages).

De Castro, R. E.; Ruiz, D. M.; Giménez, M. I.; Silveyra, M. X.; Paggi, R. A.; Maupin-Furlow, L. A., (2008). Gene cloning and heterologous synthesis of a haloalkaliphilic extracellular protease of Natrialba magadi. Extremophiles., 12 (5), 677687 (11 pages).

Dyall-Smith, M. L., (2008). The Halohandbook: Protocols for haloarchaeal Genetics. (onlinebook).

Egorova, K.; Antranikian, G.; (2007). Biotechnology. In Archaea : evolution, physiology, and molecular biology / edited by Roger Garrett and Hans-Peter Klenk. First published by Blackwell Publishing Ltd. 295-321 (27 pages).
Elevi, R.; Assa, P.; Birbir, M.; Ogan, A.; Oren, A., (2004). Characterization of extremely halophilic Archaea isolated from the Ayvalik Saltern, Turkey. World. J. Microbiol. Biotech., 20 (7), 719-725. (7 pages).

Elshahed, M. S.; Najar, F. Z.; Roe, B. A.; Oren, A.; Dewers, T. A.; Krumholz, L. R., (2004). Survey of Archaeal Diversity Reveals an Abundance of Halophilic Archaea in a Low-Salt, Sulfide- and Sulfur-Rich Spring. Appl. Environ. Microbiol., 70 (4), 2230-2239 (10 pages).

Felsenstein, J., (1985). Confidence limits on phylogenies: an approach using bootstrap. Int. J. Org. Evol., 39, 783-791 (9 pages).

Felsenstein, J., (1993). PHYLIP (Phylogeny Inference Package) version 3.5C, Distributed by the author, Department of GeneticsUniversity of Washington, Seattle.

Grant, W. D.; Kamekura, M.; McGenity, T. J.; Ventosa, A., (2001). Order I. Halobacteriales. In G. M. Garrity (man. ed.), Bergey's Manual of Systematic Bacteriology V.I, The Archaea and Deeply Branching and Phototrophic Bacteria, 2nd Ed. Springer, New York.

Jukes, T. H.; Cantor, C. R., (1969). Evolution of protein molecules. In: Munro HN (ed) Mammalian protein metabolism, vol 3. Academic Press, New York, 21-32 (12 pages).

Kumar, S.; Nei, M.; Dudley, J.; Tamura, K., (2004). Mega4: molecular evolutionary genetics analysis mega software version 4.0. Mol. Biol. Evol., 24 (8), 1596-1599 (4 pages).

Lin, Q. S.; Chen, S. H.; Hu, M. Y.; Rizwan-ul-Haq, M.; Yang, L.; Li, H., (2011). Biodegradation of cypermethrin by a newly isolated actinomycetes HU-S-01 from wastewater sludge. Int. J. Environ. Sci. Tech., 8 (1), 45-56 (12 pages).

Lizama, C.; Monteoliva-Sánchez, M.; Prado, B.; RamosCormenzana, A.; Weckesser, J.; Campos, V., (2001). Taxonomic study of extreme halophilic archaea isolated from the "Salar de Atacama", Chile. Syst. Appl. Microbiol., 24 (3), 464-474 (11 pages).

Madigan, M. T.; Oren, A., (1999). Thermophilic and halophilic extremophiles. Curr. Opin. Microbiol., 2 (3), 265-269.

Marhuenda-Egea, F. C.; Bonete, M. J., (2002). Extreme halophilic enzymes in organic solvents. Curr. Opin. biotech., 13 (4), 385-389 (5 pages).

Maturrano, L.; Santos, F.; Rosselo-Mora, R.; Anton, J., (2006). Microbial Diversity in Maras Salterns, a Hypersaline Environment in the Peruvian Andes. Appl. Environ. Microbiol., 72 (6), 3887-3895 (9 pages).

Müller-Santos, M.; Souza, E. M.; Pedrosa, F.; Mitchell, D. A.; Longhi, S.; Carrière, F.; Canaan, S.; Krieger, N., (2009). First evidence for the salt-dependent folding and activity of an esterase from the halophilic archaea Haloarcula marismortui. Biochimica. Biophys. Acta., 1791 (8), 719729 (11 pages).

Mutlu, M. B.; Martýnez-Garcýa, M.; Santos, F.; Pen, A.; Guven, K.; Anton, J., (2008). Prokaryotic diversity in Tuz Lake, a hypersaline environment in Inland Turkey. FEMS. Microbiol. Ecol., 65 (3), 474-483 (10 pages).

Oh, D.; Porter, K.; Russ, B.; Burns, D.; Dyall-Smith, M., (2009). Diversity of Haloquadratum and other haloarchaea in three, geographically distant, Australian saltern crystallizer ponds. Extremophiles, 14 (2), 161-169 (9 pages).

Onishi, H.; Mori, T.; Takeuchi, S.; Tani, K.; Kobayashi, T., (1983). Halophilic nuclease of a moderately halophilic 
Bacillus sp. Production purification and characteristics. Appl. Environ. Microbiol., 45 (1), 24-30 (7 pages).

Ozcan, B.; Cokmus, C.; Coleri, A.; Caliskan, M., (2006). Characterization of extremely halophilic Archaea isolated from saline environment in different parts of Turkey. Microbiol., 75, 739-746 (8 pages).

Park, S.; Lee, J.; Lee, H., (2000). Purification and characterization of chitinase from a marine bacterium, Vibrio sp. 98CJ11027. J. Microbiol., 38 (4), 224-229 (6 pages).

Pasic, L.; Galan Barutal, S.; Poklar Ulrih, N.; Granar, M.; Herzog-Velikonja, B., (2005). Diversity of halophilic Archaea in the crystallizers of an Adriatic solar saltern. FEMS. Microbiol. Ecol., 54 (3), 491-498 (8 pages).

Pecher, T.; Bock, A., (1981). In vivo susceptibility of halophilic and methanogenic organisms to protein synthesis inhibitors. FEMS. Microbiol. Lett., 10 (3), 295-297 (3 pages).

Purdy, K. J.; Cresswell-Maynard, T. D.; Nedwell, D. B.; McGenity, T. J.; Grant, W. D.; Timmis, K. N.; Embley, T. M., (2004). Isolation of haloarchaea that grow at low salinities. Environ. Microbiol., 6 (6), 591-595 (5 pages).

Rohban, R.; Amoozegar, M. A.; Ventosa, A., (2009). Screening and isolation of halophilic bacteria producing extracellular hydrolyses from Howz Soltan Lake, Iran. J. Ind. Microbiol. Biotech., 36 (3), 333-340 (8 pages).

Ruben, D.; Gonzalez, E.; Arenas, C.; Vilches, E. B.; De Billerbeck, M., (1993). Selective procedure for isolating microorganisms producing pullulanase and isoamylase. Biotech. Tech., 7 (6), 429-434 (6 pages).

Ruiz, D. M.; De Castro, R. E., (2007). Effect of organic solvents on the activity and stability of an extracellular protease secreted by the haloalkaliphilic archaeon Natrialba magadii. J. Ind. Microbiol. Biotech., 34 (2), 111-115 (5 pages).

Saitou, N.; Nei, M., (1987). The neighbor joining method: a new method for reconstructing phylogenetic trees. Mol. Biol. Evol., 4 (4), 406-425 (20 pages).

Samad, M. Y. A.; Razak, C. A. N.; Salleh, A. B.; Zinwan Yunus, W. M.; Ampon, K.; Basri, M., (1989). A plate assay for primary screening of lipase activity. J. Microbiol. Methods, 9 (1), 51-56 (6 pages).

Sanchez-Porro, C.; Martin, S.; Mellado, E.; Ventosa, A., (2002). Diversity of moderately halophilic bacteria producing extracellular hydrolytic enzymes. J. Appl. Microbiol., 94, 295-300 (6 pages).

Serdakowski, A. L.; Dordick, J. S., (2008). Enzyme activation for organic solvents made easy. Trends. Biotech., 26 (1), 48-54 (7 pages).

Soares Marcia, M. C. N.; De Silva, R.; Gomez, E., (1999). Screening of bacterial strains for pectinolytic activity: characterization of the polygalacturonase produced by Bacillus sp. Rev. Microbiol., 30 (4), 299-303 (5 pages).

Thompson, J. D.; Gibson, T. J.; Plewniak, F.; Jeanmougin, F.; Higgins, D. J., (1997). The clustral X windows interface: Flexible strategies for multiple sequence alignment aided by quality analysis tools. Nucleic Acids Res., 24, 48764882 ( 7 pages).

Wejse, P. L.; Ingvorsen, K., (2003). Purification and characterization of two extremely halotolerant xylanase from a novel halophilic bacterium. Extremophiles, 7 (5), 423-431 ( 9 pages).

Zhou, X. H.; Li, Z., (2004). CMCase activity assay as a method for cellulose adsorption analysis. Enzyme Microbiol. Tech., 35 (5), 455-459 (5 pages).

\section{AUTHOR (S) BIOSKETCHES}

Makhdoumi Kakhki, A., Ph.D. Candidate, Extremophiles laboratory, Department of Microbiology, College of Science, University of Tehran, Tehran, Iran. Email: makhdoumi@khayam.ut.ac.ir

Amoozegar, M. A., Ph.D., Associate Professor, Extremophiles laboratory, Department of Microbiology, College of Science, University of Tehran, Tehran, Iran. Email: amozegar@khayam.ut.ac.ir

Mahmodi Khaledi, E., Ph.D. Candidate, Extremophiles laboratory, Department of Microbiology, College of Science, University of Tehran, Tehran, Iran. Email:mahmoudi@khayam.ut.ac.ir 